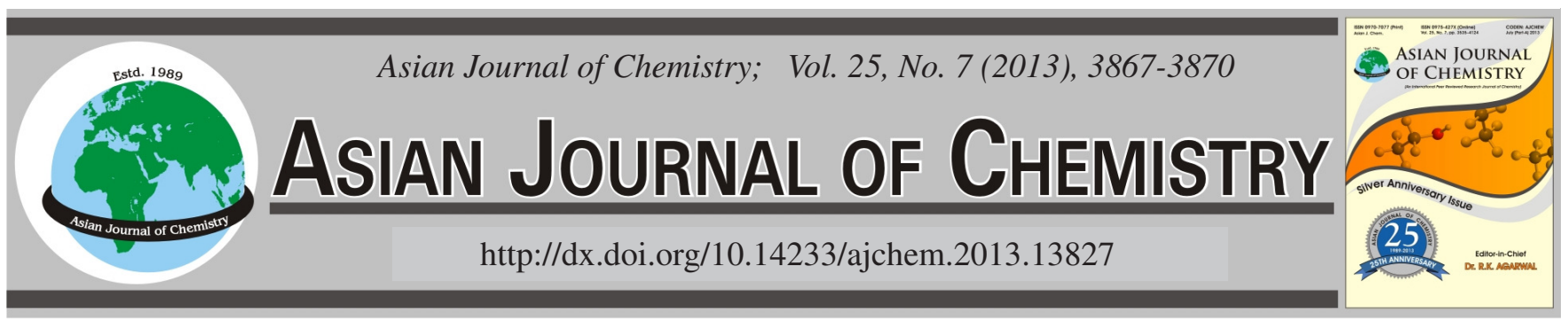

\title{
Evaluation of Heavy Metal Removal from Wastewater Using Iranain Modified Natural Clinoptilolite
}

\begin{abstract}
M. MASROURNIA
Department of Chemistry, Faculty of Science, Mashhad Branch, Islamic Azad University, P.O. Box 91735-413, Mashhad, Iran

Corresponding author: E-mail: masrour@mshdiau.ac.ir; masrournia@yahoo.com

In this study, the absorption properties of the natural zeolite (from east of Iran) with respect to some heavy metal cations in water solution were investigated. Clinoptilolite, a natural zeolite, was used for the removal of $\mathrm{Cu}^{2+}, \mathrm{Co}^{2+}, \mathrm{Ni}^{2+}$ and $\mathrm{Cd}^{2+}$ ions from water samples. The batch method has been employed. Satisfactory result was obtained by using pretreatment condition and regeneration. The percentage adsorption and distribution coefficient were determined for the absorption cations as a function of sorbate concentration. In the ion exchange evaluation, two sorption isotherms, Langmuir and Freundlich have been studied. Cation exchange selectivity can be given as $\mathrm{Cd}^{2+}>\mathrm{Cu}^{2+}$ $>\mathrm{Co}^{2+}>\mathrm{Ni}^{2+}$. These results show that these natural zeolites can be used efficiently for removal of heavy metal species from wastewater.

Key Words: Wastewater, Heavy metal, Natural zeolites, Clinoptilolite.
\end{abstract}

\section{INTRODUCTION}

Many toxic heavy metals have been dicharched into the environment as wastewater. Heavy metals can be absorbed by living organisms. They enter the food chain and the heavy metals may accumulate in the human body. They can cause serious health disorders ${ }^{1,2}$. Therefore, it is necessary to treat metal-contaminated wastewater prior to its discharge to the environment. The removal of heavy metal can be achieved by conventional treatment processes such as chemical precipitation, ion exchange and electrochemical removal ${ }^{3-6}$. These processes have many drawbacks such as incomplete removal, high-energy requirements and production of toxic sludge ${ }^{7}$. The use of alternative low cost material utilizing local resources would be advantages for treatment of processes, both to decrease the amount of wastewater produced and to improve the quality of the treated effluent ${ }^{8,9}$. The adsorbents may be of mineral, organic or biological origin, industrial by-products, agricultural wastes, biomass and polymeric materials ${ }^{10-13}$.

Natural zeolites are crystalline aluminosilicates containing pores and cavities of molecular dimensions ${ }^{14}$. Owing to zeolites structural characteristics and their adsorbent properties, they have been applied as chemical sieves, water softeners and adsorbents. Zeolites can be easily regenerated by washing them with chemical solutions (e.g., $\mathrm{NaCl}, \mathrm{CaCl}_{2}, \mathrm{KCl}, \mathrm{NaOH}$, $\mathrm{HCl}$ ) and this is one more advantage of them because they can be re-used many times without losing their adsorption capability $^{15,16}$.
For sorption applications, zeolites are often reported to exhibit high sorption capacity and selectivity for divalent elements, which makes the zeolites attractive for environmental applications, such as water softening or removing toxic metals from water ${ }^{17}$.

The advantage of zeolites over resins, apart from their much lower cost is their ion selectivity. Among the most frequently studied natural zeolites, clinoptilolite was shown to have high selectivity for certain heavy metal ions. It was demonstrated that the cation-exchange capability of clinoptilolite depends on the pre-treatment method. Modification/ pretreatment aims to replace exchangeable cations ( $\mathrm{Na}, \mathrm{K}, \mathrm{Ca}$ and $\mathrm{Mg}$ ) on clinoptilolite with a cations that is more willing to undergo ion exchange, thus improves its ion exchange ability and removal efficiency ${ }^{18,19}$. Sodium chloride seems to be the most widely used for chemical pretreatment ${ }^{20}$. Several aspect of heavy metal removal via clinoptilolite such as determination of removal capacity or pretreatment has been investigated by a number of researchers ${ }^{21-25}$.

The aim of this work is to show the capability of Iranes modified chemical clinoptilolite (MCC) in removing $\mathrm{Co}, \mathrm{Cu}$, $\mathrm{Cd}$ and $\mathrm{Ni}$ from a highly contaminated industrial water.

\section{EXPERIMENTAL}

The natural clinoptilolite used in this study is from a zeolite comes from a layer situated in South Khorasan, (Ferdows City) Iran. The clinoptilolite zeolite (CZ) was ground 
and passed through $300-600 \mu \mathrm{m}$ sieves and was dried in an oven at $100{ }^{\circ} \mathrm{C}$ for $24 \mathrm{~h}$.

Inorganic chemical were supplied by Merck as analyticalgrade regents. An initial solution of each cations were prepared from a commercial standard solution $\left(1000 \mathrm{mg} \mathrm{L}^{-1}\right)$ of cations using their nitrate salts. Deionized water $\left(18.2 \mathrm{M} \Omega \mathrm{cm}^{-1} \mathrm{MilliQ}\right.$ Plus type) was used for dilutions.

Elemental analysis for major elements in the clinoptilolite was made by using a Rigaku X-ray fluorescence analyzer (XRF) (ZSX, 100-e). Sample for major elemental analysis was prepared by mixing natural clinoptilolite zeolite powder (325 mesh, $900{ }^{\circ} \mathrm{C}$ ) with lithium tetraborate and lithium metaborate and by placing the mixture in a muffle furnace at $1100^{\circ} \mathrm{C}$ for $0.5 \mathrm{~h}$. The dried samples were then placed in the XRF apparatus.

Hitachi type SpectrAA-Z2000 Zeeman. The flame type was air-acetylene and hallow cathode lamps (Hitachi) was used with emitting wavelengths of Co $(240.7 \mathrm{~nm}), \mathrm{Cu}(324.7 \mathrm{~nm})$, $\mathrm{Cd}(228.8 \mathrm{~nm}), \mathrm{Ni}(232 \mathrm{~nm})$. The cations removal by zeolitic rocks was evaluated using a batch method.

Adsorption equilibrium measurements: All chemicals and salts used were of reagent grade. The standards solutions of cobalt, nickel, copper and cadmium cations ranging from 30 to $500 \mathrm{mg} / \mathrm{L}$ were prepared from $1000 \mathrm{mg} / \mathrm{L}$ stock standard solution of the cations with deionized water in polyethylene plastic bottles. The $\mathrm{pH}$ of the prepared solution was adjusted by adding $0.10 \mathrm{M} \mathrm{NaOH}$ or $0.1 \mathrm{M} \mathrm{HCl}$ solution and measured with the accurate $\mathrm{pH}$ meter. One gram of the zeolite was added to $50 \mathrm{~mL}$ of each solution. The bottles were closed tightly and placed on the shaker at $100 \mathrm{rpm}$ and after $48 \mathrm{~h}$, the samples were removed from the shaker, filtered $(0.45 \mu \mathrm{m}$ nylon $)$ and analyzed by AAS for cations concentration. The per cent adsorption $(\%)$ and distribution ratio $\left(\mathrm{K}_{\mathrm{d}}\right)$ was calculated using the equation

$$
\text { Adsorption }(\%)=\frac{\left(\mathrm{C}_{\mathrm{i}}-\mathrm{C}_{\mathrm{f}}\right)}{\mathrm{C}_{\mathrm{f}}} \times 100
$$

where $C_{i}$ and $C_{f}$ are the concentration of metal ion in initial and final solution, respectively.

$\mathrm{K}_{\mathrm{d}}=$ Amount of metal in adsorbent/amount of metal in solution $\times \mathrm{V} / \mathrm{m}$

where $\mathrm{V}$ is the volume of solution $(\mathrm{mL})$ and $\mathrm{m}$ is the weight of the adsorbent $(\mathrm{g})$.

\section{RESULTS AND DISCUSSION}

Physical and chemical properties of natural zeolite: Major and trace element compositions of the clinoptilolite zeolite sample showed that aside from the main $\mathrm{Si}$ and $\mathrm{Al}$ components, $\mathrm{Na}$ is the next highest component at $3.18 \mathrm{wt}$ \% followed by K at 2.44 wt. \% (Table-1). Silica to alumina ratio (Si/Al) of 5.92 was obtained for the natural clinoptilolite zeolites. The Si/Al ratio provides the negatively charged structure of the zeolite due to the difference between the $\left(\mathrm{AlO}_{4}\right)^{5-}$ and $\left(\mathrm{SiO}_{4}\right)^{4-}$ tetrahedral ${ }^{26}$. Positive sites may be available from the alkaline and alkaline-earth cations contained in the zeolite that are available for ion exchange.The XRF elemental analysis data shown in Table-1. It was found that the natural zeolite contains approximately $80 \%$ clinoptolite and main impurity identified as quartz by XRD analysis.
TABLE-1

ELEMENTAL ANALYSIS OF A NATURAL CLINOPTILOLITE ZEOLITE FROM IRAN (FERDOWS CITY)

\begin{tabular}{cccc}
\hline $\begin{array}{c}\text { Major } \\
\text { elements }\end{array}$ & $\begin{array}{c}\text { Concentration } \\
\text { (wt. \%) }\end{array}$ & $\begin{array}{c}\text { Major } \\
\text { elements }\end{array}$ & $\begin{array}{c}\text { Concentration } \\
\text { (wt. \%) }\end{array}$ \\
\hline $\mathrm{SiO}_{2}$ & 63.37 & $\mathrm{MnO}$ & 0.02 \\
$\mathrm{Al}_{2} \mathrm{O}_{3}$ & 10.71 & $\mathrm{CaO}$ & 1.69 \\
$\mathrm{Na}_{2} \mathrm{O}$ & 4.09 & $\mathrm{P}_{2} \mathrm{O}_{5}$ & 0.05 \\
$\mathrm{MgO}$ & 1.20 & $\mathrm{Fe}_{2} \mathrm{O}_{3}$ & 2.15 \\
$\mathrm{~K}_{2} \mathrm{O}$ & 2.00 & $\mathrm{SO}_{3}$ & 0.53 \\
$\mathrm{TiO}_{2}$ & 0.34 & LOI & 12.87 \\
\hline
\end{tabular}

Modification of natural zeolit: Different modifier materials ( $\mathrm{NaCl}, \mathrm{MgCl}_{2}, \mathrm{KCl}, \mathrm{HCl}$ ) were tested for pretreatment and regeneration. For this purpes $1 \mathrm{~g}$ of zeolite with $50 \mathrm{~mL}$ of $1 \mathrm{M}$ of modifier were placed on shaker at $25^{\circ} \mathrm{C}$ and $100 \mathrm{rpm}$ for $24 \mathrm{~h}$. After that washed with water until no $\mathrm{Cl}^{-}$was detected in washing water. The pretreated samples were dried at $100{ }^{\circ} \mathrm{C}$ for $24 \mathrm{~h}$ and stored in desiccators for further use. The regeneration of zeolite after removal cations from sample were used was performed under the same experimental procedure as the pretreatment step.

Fig. 1 shows the result of using modifiers for cations removal capacity sorbent. These result indicated that $\mathrm{NaCl}$ increased the metal removal. $\mathrm{NaCl}$-modified clinoptilolite resulted higher cation uptake. This is in agreement with previous studies $^{18,20}$.

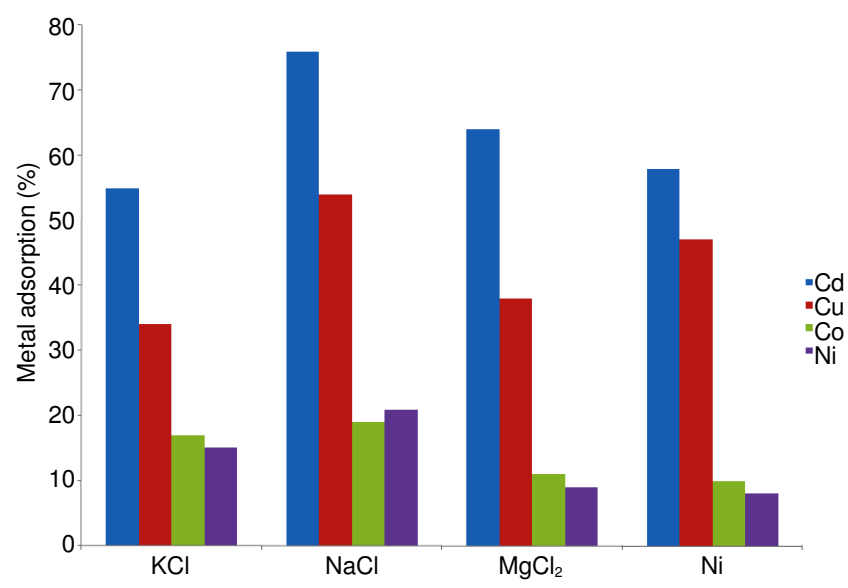

Fig. 1. Result of using modifiers for cations on removal capacity sorbent

Effect of pH on cation adsorption: The effect of $\mathrm{pH}$ on cations adsorption by clinoptilolite zeolite was investigated at acidic, neutral and basic conditions. The $\mathrm{pH}$ of eight $50 \mathrm{~mL}$ solutions of each cation $100 \mathrm{mg} / \mathrm{L}$ was adjusted to values ranging from 3 to 8 (each $\mathrm{pH}$ level in duplicate) by adding 0.1 $\mathrm{M} \mathrm{HCl}$ or $0.1 \mathrm{M} \mathrm{NaOH}$. Initial $\mathrm{pH}$-values were recorded. The solutions were then mixed with $1 \mathrm{~g}$ of clinoptilolite zeolite in $500 \mathrm{~mL}$, high-density, polyethylene plastic bottles and placed in an automatic shaker at $100 \mathrm{rpm}$ for $48 \mathrm{~h}$ to ensure that adsorption equilibrium was obtained. After $48 \mathrm{~h}$, samples were removed from the shaker, filtered $(0.45 \mu$ mylon $)$ and analyzed with an atomic absorption spectrometer (AAS). The $\mathrm{pH}$ of the initial test solution significantly affected cation uptake over the $\mathrm{pH}$ range (3-8) investigated (Fig. 2). The $\mathrm{pH}$ of the aqueous solution is an important controlling parameter in the sorption process. Since most specifically sorbet metal ions can form 


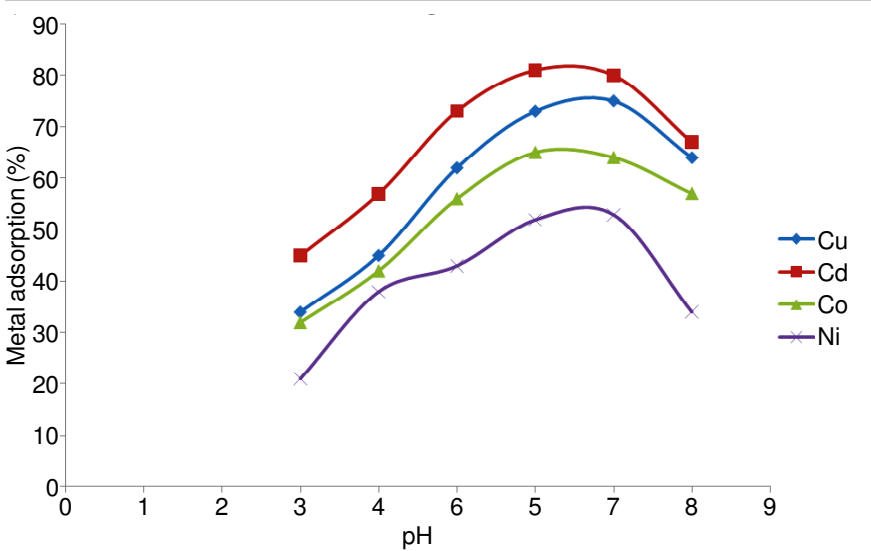

Fig. 2. Effect of $\mathrm{pH}$ on cations adsorption

oxides and hydrous oxides, the potential for heterogeneous precipitation will always be present in aqueous systems because of the presence of the constituent $\mathrm{OH}$, ion as coordinated water molecules, hydroxyl species of cations may participate onto the zeolite structure especially at $\mathrm{pH}$ above 8 . However, such a process could happen for samples with high cation initial concentrations. The extremely weak sorption found at $\mathrm{pH} 3$ was also excluded as it likely resulted probably due to competition of $\mathrm{H}^{+}$at low $\mathrm{pH}$, more $\mathrm{H}^{+}$occupied the surface of the adsorbent, reducing the access of cation ions to surface sites resulting in a decrease in cation uptake onto clinoptilolite. The optimum pH 6-7 was chosen for uptake of $\mathrm{Cd}, \mathrm{Cu}, \mathrm{Ni}$ and $\mathrm{Co}$ cations.

Adsorption of cations on modified clinoptilolite: The adsorption of cations onto the natural zeolite was studied by varying the metal concentration from 10 to $500 \mathrm{mg} / \mathrm{L}$ while keeping all parameter constant. Percentage absorption and $\mathrm{K}_{\mathrm{d}}$ values for cations decrease with increasing metal ion concentration. The results are shown in Figs. 3 and 4. These results indicate that less favorite sites involved with increasing cation concentrations. The amounts of metal ions removed by the clinoptilolite based on the $48 \mathrm{~h}$ batch equilibrium. The retention of ions are ranked as based on percentage mass removal. The results show that there is $81.48 \%$ of $\mathrm{Cd}^{2+}, 75 \%$ of $\mathrm{Cu}^{2+}, 67 \%$ of $\mathrm{Co}^{2+}$ and $50 \%$ of $\mathrm{Ni}^{2+}$ removal from modified chemical clinoptilolite. The retention of ions are ranked as $\mathrm{Cd}^{2+}>\mathrm{Cu}^{2+}$ $>\mathrm{Co}^{2+}>\mathrm{Ni}^{2+}$ based on percentage mass removal. It is known that ion exchange selectivity is determined by the strength of electrostatic forces. Since electrostatic forces are involved in the retention of counter ions, it can be predicted from Coulomb's law that the ion having the smallest "effective" radius will be preferred. As cations present in solution are hydrated, ions with the smaller hydrated size or larger crystalline size are preferred. It has been demonstrated ${ }^{26}$ that there is a definite relationship between ion size and ion selectivity.

Batch isotherm studies: The selection of appropriate correlation models for the experimental equilibrium data is important in order to optimize the design of an adsorption system for the removal of cations. Freundlich and Langmuir isotherm models have been demonstrated to fit the equilibrium behaviour of heavy metals ${ }^{27-28}$. These two models were used to correlate the observed behaviour in the present study. The adsorption equilibrium data obtained at $\mathrm{pH}$ 6-7 for solutions with initial cations concentrations varying from 30 to $500 \mathrm{mg} / \mathrm{L}$.

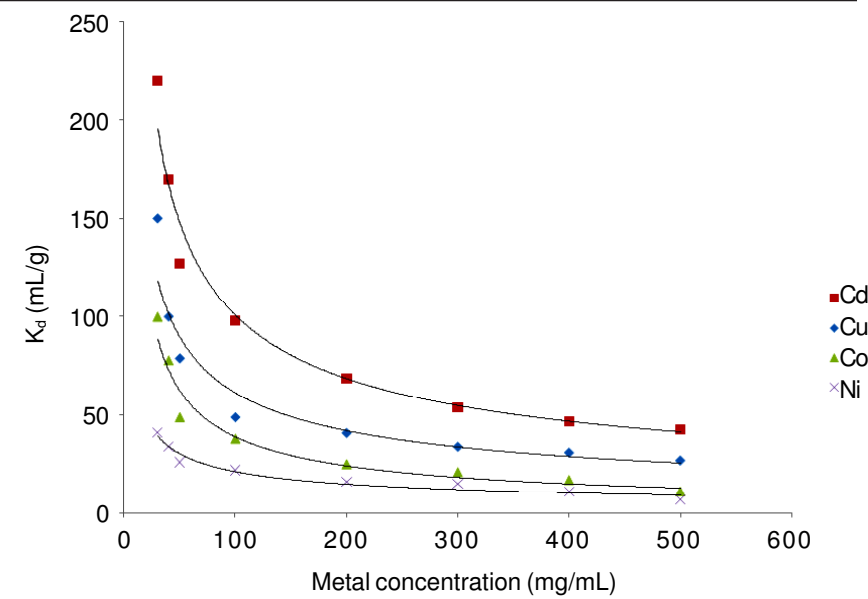

Fig. 3. Distribution ratio $\left(\mathrm{K}_{\mathrm{d}}\right)$ metal ions on clinoptilolite as a function of initial concentration: $\mathrm{m}=1 \mathrm{~g}, \mathrm{~V}=50 \mathrm{~mL}, \mathrm{pH}$ 6-7, time $48 \mathrm{~h}$

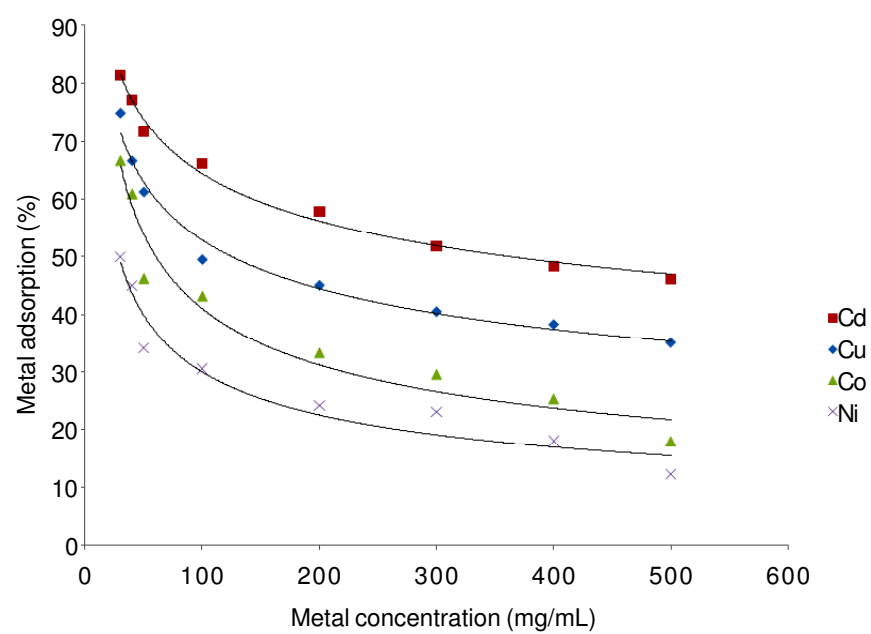

Fig. 4. Per cent adsorption as a function initial concentration: $\mathrm{m}=1 \mathrm{~g}, \mathrm{~V}=$ $50 \mathrm{~mL}, \mathrm{pH}$ 6-7, time $48 \mathrm{~h}$

The Freundlich model indicates the heterogeneity of the adsorbent material and is given by the equation

$$
\log \mathrm{q}=\log \mathrm{K}+\frac{1}{\mathrm{n}} \log \mathrm{C}_{\mathrm{e}}
$$

where $\mathrm{q}(\mathrm{mg} / \mathrm{g})$ is the amount of cation adsorbed at equilibrium, $C_{e}(\mathrm{mg} / \mathrm{L})$ is the equilibrium concentration of cation in solution and $\mathrm{K}$ and $\mathrm{n}$ are the Freundlich constants related to the zeolite adsorption capacity and adsorption intensity, respectively.

This isotherm does not predicate any saturation of the sorbent and indicate multilayer adsorption on the surface.

The Langmuir isotherm model assumes the formation of a monolayer onto the adsorbent surface with a finite number of identical sites and is given by the equation

$$
\frac{\mathrm{C}_{\mathrm{e}}}{\mathrm{q}}=\frac{1}{\mathrm{~K}_{\mathrm{L}}}+\left(\frac{\mathrm{a}}{\mathrm{K}_{\mathrm{L}}}\right) \mathrm{C}_{\mathrm{e}}
$$

where, $\mathrm{K}_{\mathrm{L}}$ and a are the Langmuir constants.

A linear plot is obtained when $C_{e} / q$ are plotted against over the entire concentration range of metal ions investigated. Results of the isotherm studies were fitted into both the Freundlich and the Langmuir isotherms. 
The parameters for the Freundlich and Langmuir models are presented in Table-2. The high values of $\mathrm{K}$ suggested that adsorption capacity of the adsorbent is high. Low $1 / \mathrm{n}$ values $(<1)$ from the Freundlich isotherm suggested that any large change in the equilibrium concentration of cations would not result in a marked change in the amount of cation sorbet. The correlation coefficient $(\mathrm{R})$ for all the isotherms ranged between 0.95 and 0.99 , representing an excellent fit of the observed data. The $t$-test values showed that the coefficients were not significant at the $95 \%$ confidence level for all the model equations.

TABLE-2

ADSORPTION ISOTHERM MODEL PARAMETERS

\begin{tabular}{cccc|ccc}
\hline \multirow{2}{*}{ Element } & \multicolumn{2}{c|}{ Freundlich isotherm } & \multicolumn{3}{c}{ Langmuir isotherm } \\
\cline { 2 - 7 } & $\mathrm{K}$ & $1 / \mathrm{n}$ & $\mathrm{R}^{2}$ & $\mathrm{a}$ & $\mathrm{K}_{\mathrm{L}}$ & $\mathrm{R}^{2}$ \\
\hline $\mathrm{Cd}$ & 1.41 & 0.30 & 0.9920 & 0.13 & 0.0180 & 0.9987 \\
$\mathrm{Cu}$ & 3.79 & 0.34 & 0.9875 & 0.08 & 0.0090 & 0.9835 \\
$\mathrm{Co}$ & 1.34 & 0.36 & 0.9532 & 0.03 & 0.0035 & 0.9563 \\
$\mathrm{Ni}$ & 5.18 & 0.45 & 0.9808 & 0.01 & 0.0002 & 0.9989 \\
\hline
\end{tabular}

\section{Conclusion}

Since clinoptilolite has a molecular sieve structure, the adsorption of ions depends on the size of the hydrated ion and whether it can fit into the clinoptilolite channel, as well as the charge and concentration of ions. These results of ion adsorption can be explained by the classification of metal ions in the Periodic Table. The ion retention can also be explained by the binding strength, derived from the Langmuir equation from the ion adsorption isotherms. The constants related to binding strength, the selectivity of the metals for binding sites is ordered $\mathrm{Cd}^{2+}>\mathrm{Cu}^{2+}>\mathrm{Co}^{2+}>\mathrm{Ni}^{2+}$ on the surface of the clinoptilolite.

The adsorption chractristic of the zeolite is dependent upon the chemical and structural properties of sorbent. These properties can be changed by several chemical treatments to improve separation efficiency of natural zeolite. The use of $\mathrm{NaCl}$ would allow zeolite exchangeable cations ( $\mathrm{Na}, \mathrm{K}, \mathrm{Mg}$, Ca) to its homoionic Na-form. Sodium as compare to other cations $(\mathrm{K}, \mathrm{Mg}, \mathrm{Ca})$ has high mobility and weakly bonded and make replacement of with conceded cations easier ${ }^{20}$.

These results show that natural zeolite can be used effectively for the removal of metal cations from wastewater. This natural material provided suitable substitute as sorbent with availability low cost materials.

\section{ACKNOWLEDGEMENTS}

The author acknowledged the financial support from the Complementary Education Management of Islamic Azad University, Mashhad Branch, Iran.

\section{REFERENCES}

1. S. Babel and T.A. Kurniawan, J. Hazard. Mater. B, 97, 219 (2003).

2. V.J. Inglezakis, M.D. Loizidou and H.P. Grigoropoulou, J. Colloid Interf. Sci., 261, 49 (2003).

3. A.J. Pedersen, Biomass Bioenergy, 25, 447 (2003).

4. T.A. Kurniawan, G.Y. S. Chan, W.H. Lo and S. Babel, Chem. Eng. J., 118 (2006).

5. V.J. Inglezakis, M.M. Loizidou and H.P. Grigoropoulou, J. Colloid Interf. Sci., 75, 570 (2004).

6. L.E. Applegate, Chem. Eng., 91, 64 (1984)

7. H. Eccles, Trends Biotechnol., 17, 462 (1999).

8. T.A. Kurniawan, G.Y.S. Chan, W.H. Lo and S. Babel, Sci. Total Environ., 366, 409 (2005).

9. M.G. Khedr, Desalination, 222, 135 (2008)

10. T.Y. Lee, J.W. Park and J.H. Lee, Chemosphere, 56, 571 (2004).

11. W.C. Leung, M.F. Wong, H. Chua, W. Lo and C.K. Leung, Water Sci. Technol., 41, 233 (2000).

12. X.D. Liu, S. Tokura, N. Nishi and N. Sakairi, Polymer, 44, 1021 (2003).

13. G. Crini, Prog. Polym. Sci., 30, 38 (2003).

14. S.B. Wang, H.T. Li, S.J. Xie, S.L. Liu and L.Y. Xu, Chemosphere, 65 , 82 (2007).

15. H. Ghobarkar, O. Schaf and U. Guth, Prog. Solid State Chem., 27, 29 (1999).

16. A. Dimirkou, A. Ioannou and M. Doula, Adv. Colloid Interf. Sci., 97, 37 (2002).

17. L. Curkovic, S. Cerjan-Stefanovic and T. Filipan, Water Res., 31, 1379 (1997).

18. P. Bose, M.A. Bose and S. Kumar, Adv. Environ. Res., 7, 179 (2002).

19. K. Gedik and I. Imamoglu, J. Hazard. Mater., 155, 385 (2008).

20. A. Dimirkou and M.K. Doula, Desalination, 224, 280 (2008).

21. K. Gedik and I. Imamoglu, Sep. Sci. Technol., 43, 1191 (2008).

22. M. Sprynskyy, B. Buszewski, A.P. Terzyk and J. Naniesnik, J. Colloid Interf. Sci., 304, 21 (2006).

23. K.B. Payne and T.M. Abdel-Fattah, J. Environ. Sci. Health A, 39, 2275 (2004).

24. O. Oter and H. Akcay, Water. Environ. Res., 79, 329 (2007).

25. T. Armbruster and M.E. Gunter, Crystal Structures of Natural Zeolites, Natural Zeolites: Occurrence, Properties, Applications, Series Editor Blacksburg, Virginia, pp. 1-67 (2001).

26. L.Y. Li, Clay Sci., 12, 73 (2003).

27. M. Trag, J. Peric and N.V. Medvidovic, J. Hazard. Mater., 136, 938 (2006).

28. I. Langmuir, J. Am. Chem. Soc., 40, 1361 (1918). 